\title{
TRACE ELEMENTS IN SPELEOTHEMS. A short review of the state of the art
}

\author{
Sophie Verheyden
}

\begin{abstract}
A state of the art of the research on trace elements of speleothems is given. First studies focussed on problems such as the colour of speleothems and the aragonite problem. Insitu studies and studies oriented towards a better understanding of vadose hydrology brought new insights in the controls on trace elemental composition of speleothems. Recent studies deal with microscale analyses and annual and intra-annual chemistry changes. Further in-situ studies should be performed to further differentiate influences, such as climate, soil/weathering and local hydrology in order to better constrain possible transfer functions between the surface and a speleothem.
\end{abstract}

Keywords: speleothems, trace elements, color, paleo-envirnment

\section{The colour of speleothems}

First studies on trace elements in speleothems (James, 1997 and references herein) focused mainly on possible explanations for the colour of speleothems (White, 1997 and references herein). A particular coloration of a speleothem may be due to the presence of certain minor and/or trace constituents. However, there is no direct relationship between trace element content and colour, and moreover other substances such as organic acids can also colour speleothems (Gascoyne, 1977). Genty showed that the visible distinction between white and dark layers in a laminated speleothem from the Godarville tunnel (Belgium) is due to a difference in porosity with a much higher porosity for the white layers (Genty, 1992; Genty et al., 1997) (figure 1).

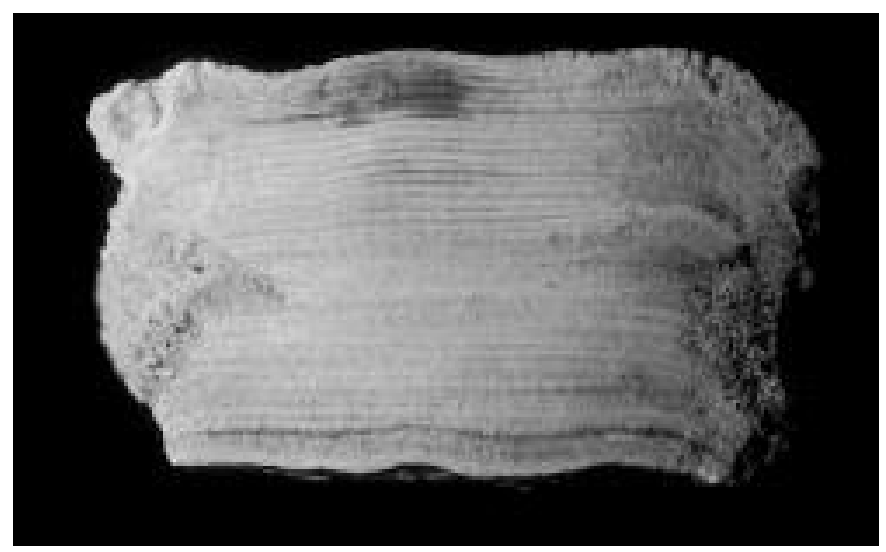

Figure 1:

Cross section of a 30 -years old stalagmite $(5 \mathrm{~cm}$ high) of the Godarville tunnel (Belgium). It is annually laminated with an alternation of dark translucent compact and white porous layers. 


\section{The aragonite problem}

The calcite-aragonite problem was another main topic in the first trace element studies in speleothems (Hill and Forti, 1997 and references herein). At low temperatures, inorganic aragonite is a meta-stable form of calcium carbonate. Nevertheless primary precipitated aragonite is found in the cave environment. This is explained by a high $\mathrm{Mg} / \mathrm{Ca}$ ratio of the precipitating solution, i.e. the cave water, with an additional influence of the saturation state, the speleothem surface and the $\mathrm{CO}^{2}$ content of the cave water and air (Holland et al., 1964; Given and Wilkinson, 1985; Hill and Forti, 1997 and references herein).

\section{The in-situ studies}

With the availability of precise analytical techniques and with the increasing interest in the climatic and environmental topics, the number of geochemical studies in the cave environment increased. The first important study of the chemical composition of cave waters was done by Holland et al. (1964) with the determination of the partition coefficient of Sr between cave waters and cave calcite in the Lurray Caverns in Virginia (North-America). They found that partition coefficients for $\mathrm{Sr}$ calculated from the $\mathrm{Sr}$ content of cave waters and deposits in the Lurray Caverns in Virginia were in good agreement with DSr of 0.14 determined in the laboratory. Recently Huang and Fairchild (2001) obtained new values for DSr and DMg during a karst-analogue calcite deposition experiment in order to study the different controls on the $\mathrm{Mg}$ and $\mathrm{Sr}$ incorporation of a speleothem. In a broad study of Carlsbad Cavern (N-America) cave waters and calcites, Gonzales and Lohmann (1988) found a large variability of cave waters compositions due to degassing, evaporation and carbonate precipitation processes. The enrichment of Soreq cave waters (Israel) in $\mathrm{Mg}^{2+}$ was explained by Bar-Matthews et al. (1991) as due to prior low-Mg calcite precipitation from the cave waters, which are consequently enriched in $\mathrm{Mg}^{2+}$. Prior calcite precipitation was also observed in the Père Noël cave (Belgium) (figure2) (Verheyden et al., 2000) and in the Clamouse cave (S-France) by Fairchild et al. (2000) who demonstrated that it is a powerful mechanism for generating enhanced and covarying $\mathrm{Mg} / \mathrm{Ca}$ and $\mathrm{Sr} / \mathrm{Ca}$ ratios. Anti-correlation between annual $\mathrm{Mg} / \mathrm{Ca}$ and $\mathrm{Sr} / \mathrm{Ca}$ cycles in speleothems was also observed and explained by Roberts et al. (1998) and Fairchild et al. (2000) as due to incongruent dolomite dissolution. The seasonal changes are probably due to variations in the water residence time in the vadose zone, linked to changes in amount of precipitation. These studies demonstrated that the changes in chemistry of cave waters, and consequently in speleothems, could reflect changes in effective precipitation (or recharge) (Roberts et al., 1998; Fairchild et al., 1999, 2000; Verheyden et al., 2000). Incongruent dolomite dissolution was also demonstrated to be responsible for the anti-correlation between $\mathrm{Mg}$ and $\mathrm{Sr}$ content and between $\mathrm{Ba}$ and $\mathrm{Mg}$ content in a New Zealand flowstone by Hellstrom et al., (2000). Changes in the contribution of weathering linked with changes in rainfall intensity were invoked to explain changes in the $\mathrm{Sr}, \mathrm{Ba}$ and $\mathrm{U}$ contents of speleothems by Bar-Matthews et al. (1999) and Ayalon et al. (1999). During colder and dryer periods, higher trace element concentrations reflect an increase in exogenic sources (sea spray and Aeolian dusts), and a reduced contribution of weathering from the host dolomites. 


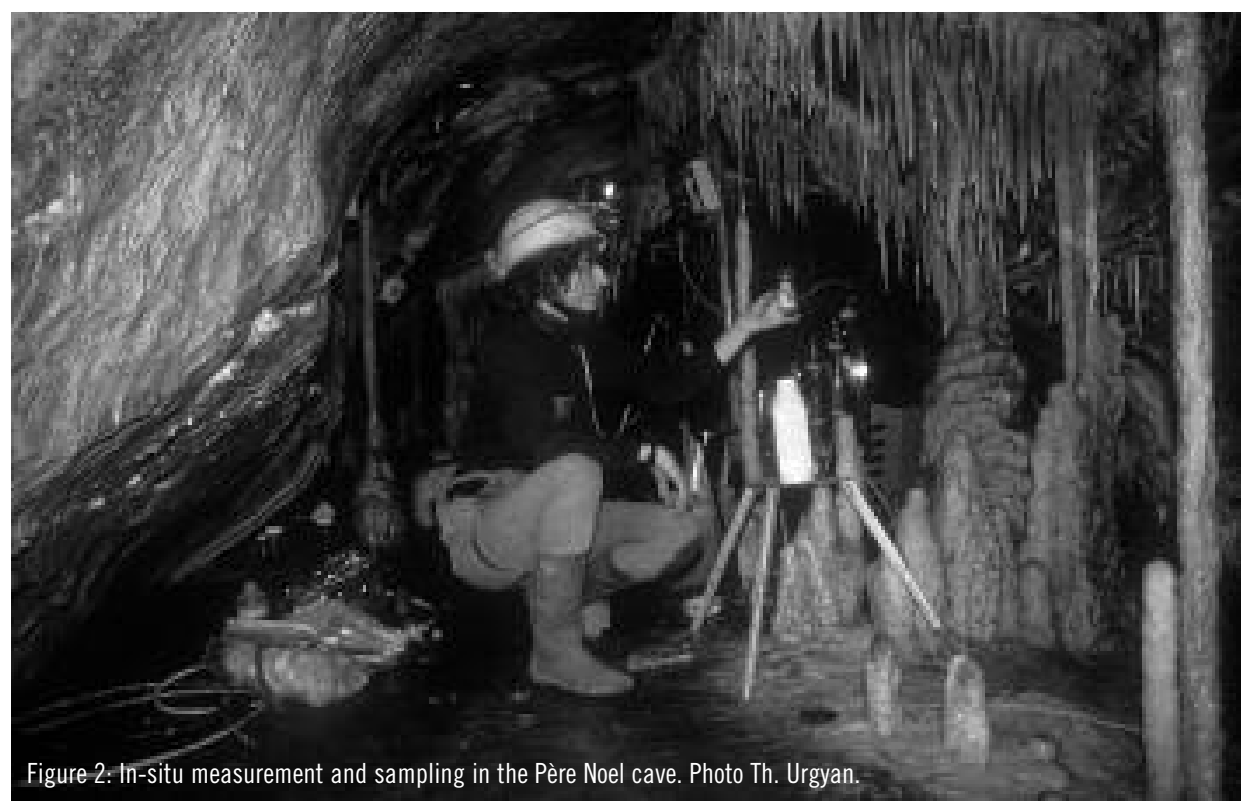

\section{Vadose hydrology}

The study by Bottrell and Atkinson (1992) of seepage water and tracing in a karstic limestone in Yorkshire, England, revealed complex flow patterns of the seepage water with different residence times depending on the flow route of the waters. Perrin (1997) observed, as expected, an increase of the ion concentration of cave waters with increasing cave depth, reflecting the increase in water-rock interaction time. He observed a lower ion concentration in more slowly dripping waters in the "réseau du grand Cor" (Valais, Switzerland) and suggested that a distinction must be made between slow and fast dripping cave waters. In shallow caves, fast-dripping places may record heavy rainfall periods by an increase in the drip rate and a negative peak in conductivity, with a response of a few hours, while slow-dripping places do not (Borsato, 1997). These observations are in agreement with the studies of Perrette (1999), Destombes et al. (1997) and Delannoy et al. (1999). These authors model the hierarchisation of the drainage system and make the distinction between a transmissive system or vertical water flow through fractures, and a capacitive system or the water reservoir contained in the microfractures. Different information will be registered in stalagmites deposited by seepage water coming through the different systems. These studies demonstrate the importance of the flow route and residence time of the vadose water. However, processes going on at the surface above the cave can also influence the chemical composition of the cave waters and as a consequence of the speleothems. Goede 1994 and Goede et al., 1998 explained the bimodal distribution of the $\mathrm{Sr}$ content of a Tasmanian stalagmite deposited between 80 and 60 alpha-U/Th years BP as due to rapid changes of dominant strong winds inducing variations in the $\mathrm{Sr}$ contribution from terrestrial dust deposited at the surface above the cave. 


\section{Temperature dependent Mg partitioning}

Since Mg incorporation in calcite is temperature dependent, Gascoyne $(1983,1992)$ stated that changes in the $\mathrm{Mg}$ content of a speleothem can be used to reconstruct air surface temperature changes, since in most shallow caves, the calcite precipitation temperature or cave temperature is an annual mean of the surface air temperature. By measuring the $\mathrm{Mg}$ content of cave seepage waters and associated calcite deposits in caves from Vancouver Island and Jamaica, he found average partition coefficients for $\mathrm{Mg}$ in calcite of 0.017 (Vancouver Island, $7{ }^{\circ} \mathrm{C}$ ) and 0.045 (Jamaica, $23^{\circ} \mathrm{C}$ ). He calculated that a $1{ }^{\circ} \mathrm{C}$ increase would increase the $\mathrm{Mg}$ content of the stalagmite with $7 \%$. A positive trend in $\mathrm{Mg} / \mathrm{Sr}$ content (as well as a negative trend in $\mathrm{Br}$ content) in a Late Glacial Tasmanian speleothem was believed to be temperature related by Goede and Vogel (1991). However, Goede (1994) found no correlation between $\mathrm{Mg}$ content and $\delta^{18} \mathrm{O}$ time-series in a Tasmanian stalagmite deposited between 98 and $55 \mathrm{ka}$ BP. Recent studies link Mg changes more probably to changes in the water residence time.

\section{Coeval speleothems - implication for paleoclimatic studies}

Roberts et al. (1999) bring some serious doubts about whether trace element changes in speleothems may reflect palaeo-environmental changes. They measured $\mathrm{Mg}, \mathrm{Sr}$ and $\mathrm{Ba}$ concentration changes in three coeval stalagmites from a cave in Great-Britain based on LA-ICP-MS and found no coherence between records from the different stalagmites. Their model suggests a strong control of hydrological mixing of waters in the epikarstic zone, which have interacted with two geochemically distinct source rocks (calcitic limestone and dolomite). Therefore it is possible that climatic signals were overruled by other forcings due to the particular geological setting.

\section{Annual cyclicity and future studies}

Recent results focus on the microscale analysis possible by new, more sophisticated and high-resolution techniques, to try to understand annual and intra-annual changes in speleothem chemistry. Annual cyclicity gives the possibility to determine the growth rate of the speleothem and in some cases to date a speleothem by cycle counting in the absence of visible laminae. It is now clear that minor and trace elements ( $\mathrm{Sr}, \mathrm{Mg}, \mathrm{F}, \mathrm{P}$, $\mathrm{Na}, \mathrm{Fe}, \mathrm{Zn}, \mathrm{Si}$ ) display an annual cyclicity in laminated calcite speleothems (Fairchild et al., 2001, Huang et al., 2001, Kuczumow et al., 2003) and probably also in aragonitic speleothems (Ba/Ca) Finch et al. (2001). But trace elements in speleothems give much more information than only growth parameters. It becomes clear that the main climatic control on these trace elements in speleothems is the water availability, i.e. the effective rainfall or recharge with an increase of the $\mathrm{Me}^{2+} / \mathrm{Ca}$ ratios in dryer periods. Growth rate effects seem to be important for $\mathrm{Sr}$ and Na. Phosphor is directly linked with the vegetation productivity and decay. Huang et al. (2001) suggested an increase in P in autumn, aided by the high water infiltration rates, also common in autumn in temperate regions. $P$ could therefore be useful as an annual marker in the absence of visible laminae.

Further studies should focus on two particular fields: i) in-situ studies on the nowadays functioning and ii) general microscale trace element studies in speleothem calcite, given its particular growth. In-situ studies with monitoring of local climatic cave conditions 
and analyses on cave seepage waters give a view on the transfer functions of elements, the relation between the surface (climate, vegetation), the geology (host rock, hydrological patterns) and local cave climatology (evaporation, $\mathrm{PCO}_{2}$, ). It gives understanding in the sub-annual variations of trace elements in the cave waters, which can be compared to variations in trace element content and variations in modern deposits. Especially, the knowledge of the partitioning between water and calcite at low elemental concentrations and the controls on the partitioning (water saturation and cave air $\mathrm{PCO}_{2}$ for exemple), would be useful to predict the trace element behaviour in the speleothem. In parallel, the data obtained in modern deposits should be compared to available meteorological and historical data to further study the link with climate and to establish a reliable base for palaeoclimatic studies. It is clear that a small candle shaped stalagmite continuously fed by a constant drip rate will not give the same paleoclimatic information through its trace element content then a big "shower" fed stalagmite with variable drip rates, directly linked with surface precipitation. Local arrangement should therefore always be taken into account, since they would enable the making of a kind of guide to sample a speleothem in relation with the wished climatic information, also useful regarding of course the preservation problems of speleothems.

\section{References}

Ayalon, A., Bar-Matthews M., Kaufman A., 1999 - Petrography, strontium, barium and uranium concentrations, and strontium and uranium isotope ratios in speleothems as palaeoclimatic proxies: Soreq cave, Israel. The Holocene 9 (6): 715722.

Bar-Matthews M., Ayalon A., Kaufman A., Wasserburg G.J., 1999 - The Eastern Mediterranean paleoclimate as a reflection of regional events: Soreq cave Israel. Earth and Planetary Science Letters 166: 8595.

Bar-Matthews M., Matthews A., Ayalon A., 1991 - Environmental controls of speleothem mineralogy in a karstic dolomitic terrain (Soreq cave, Israel). Journal of Geology 99: 189207.

Borsato A., 1997 - Dripwater monitoring at Grotta di Ernesto (NE Italy): a contribution to the understanding of karst hydrology and the kinetics of carbonate dissolution. Proc. of the $12^{\text {th }}$ Int. Congr. of Speleology, La Chaux-de-Fonds, Switzerland 2: 57-60.

Bottrell S.H., Atkinson T.C., 1992 - Tracer study of flow and storage in the unsaturated zone of a karstic limestone aquifer. Tracer hydrology, Proc. of the $6^{\text {th }}$. Int. Symp. on water tracing, Karlsruhe: 207211.

Delannoy J.J., Peiry J.L., Destombes J.L., Perrette Y., 1999 - Articulation des aspects expérimentaux théoriques et méthodologiques de l'étude d'un système karstique à des fins environnementales: le laboratoire de Choranche. Etudes de géographie physique, supplément $n^{0}$ XXVIII, Karst 99, European Conf.: 7782.

Destombes J.L., Cordonnier M., Gadat J.Y., Delannoy J.J., 1997 - Periodic and aperiodic forcing of water flow through sodastraw stalactites (Choranche, Vercors, France). Proc. $6^{\text {th }}$ Conf. on Limestone Hydrology and Fissured Media, Switzerland: 6973.

Fairchild I.J., Baker A., Borsato A., , Frisia S., Hinton R.W., Mcdermott F., Tooth A.F., 2001 - Annual to sub-annual resolution of multiple trace-element trends in speleothems. Journal of the Geological Society London, 158: 831841.

Fairchild I.J., Borsato A., Tooth A.F., Frisia S., Hawkesworth C.J., Huang Y., Mcdermott F., Spiro B., 2000 - Controls on trace element (SrMg) compositions of carbonate cave waters: implications for 
speleothem climatic records. Chemical Geology 166: 255269.

Fairchild I.J., Tooth A.F., Huang Y., Borsato A., Frisia S., Mcdermott F., Spiro B., 1999 - Bedrock and climatic controls on the cationic composition of karst waters. In: Geochemistry of the Earth's surface, Proc. of the fifth Int. Symp. on the geochemistry of the Earth's Surface, ed. Armannson H., Balkema, Rotterdam: 8790.

Finch A.A., Shaw P.A., Weedon G.P., Holmgren K., 2001 - Trace element variation in speleothem aragonite: potential for palaeoclimatic reconstruction. Earth and Planetary Science Letters 186: 255267.

Gascoyne M., 1977 - Trace element geochemistry of speleothems. Proceedings of the 7th Intern. Speleol. Congress, Sheffield, England: 205-207.

Gascoyne M., 1983 - Trace element partition coefficients in the calcite-water system and their paleoclimatic significance in cave studies. Journal of Hydrology 61: 213222.

Gascoyne M., 1992 - Palaeoclimate determination from cave calcite deposits. Quaternary Science Reviews 11: 609632.

Genty D., 1992 - Les spéléothemes du tunnel de Godarville(Belgique): un exemple exèptionnel de concrétionnement moderne. Intérêt pour l'étude de la cinétique de la précipitation de la calcite et de sa relation avec les variations d'environnements. Spéléochronos 4: 3-29.

Genty D., Deflandre G., Quinif Y., Verheyden S., 1997 - Les lamines de croissance des spéléothèmes: origine et interêt paléoclimatique. Bull. de la Soc. belge de Géol. T106: 6377.

Given R.K. and Wilkinson B.H., 1985. Kinetic control of morphology, composition and mineralogy of abiotic sedimentary carbonates. Journal of Sedimentary Petrology 55 (1): 109119.

Goede A., 1994 - Continuous early last glacial palaeoenvironmental record from a Tasmanian speleothem based on stable isotope and minor element variations. Quaternary Science Reviews 13: 283291.

Goede A., Vogel J.C., 1991 - Trace element variations and dating of a Late Pleistocene Tasmanian speleothem. Palaeogeography, Palaeoclimatology Palaeoecology 88: 121131.

Goede A., Mcculloch M., Mcdermott F., Hawkesworth Ch., 1998 - Aeolian contribution to strontium and strontium isotope variations in a Tasmanian speleothem. Chemical Geology 149: 3750.

Gonzales L.A., Lohmann K.C., 1988 - Controls on mineralogy and composition of spelean cabonates: Carlsbad caverns, New Mexico. In: Paleokarst, N.P. James and P.W. Choquette, eds., Springer-Verlag N.Y.: 81101.

Hellstrom J.C., Mcculloch M.T., 2000 - Multi-proxy constraints on the climatic significance of trace element records from a New Zealand speleothem. Earth and Planetary Science Letters 179: 287297.

Hill C.A., Forti P., 1997 - The calcite-aragonite problem. In: Cave minerals of the world. Hill C.A., Forti P., eds. National Speleological Society: 237239.

Holland H.D., Kirsipu T.V., Huebner J.S., Oxburgh U.M., 1964 - On some aspects of the chemical evolution of cave waters. Journal of Geology 72: 3667.

Huang Y., Fairchild I.J., 2001 - Partitioning of $\mathrm{Sr}^{2+}$ and $\mathrm{Mg}^{2+}$ into calcite under karstanalogue experimental conditions. Geochimica et Cosmochimica Acta 65 (1): 4762.

Huang Y., Fairchild I.J., Borsato A., Frisia S., Cassidy N.J., Mcdermott F., Hawkesworth C.J., 2001 Seasonal variations in Sr, Mg and P in modern speleothems (Grotta di Ernesto, Italy). Chemical Geology 175: 429448.

James J.M., 1997 - Minor, trace and ultra-trace constituents of speleothems. In: cave minerals of the world. Hill C.A. and Forti P., eds. National Speleological Society: 236237.

Kuczumow A., Genty D., Chevallier P., Nowak J., Ro CU., 2003 - Annual resolution analysis of a SWFrance stalagmite by Xray synchrotron microprobe analysis. Spectrochimica Acta Part B 58: 851865. 
Perrette Y., 1999 - Les stalagmites: archives environnementales et climatiques à haute résolution. Karstologia 34 (2): 2344.

Perrin J., 1997 - Géologie et géochimie des eaux dans le réseau du Grand Cor (Valais, Suisse). Proc. of the 12th Int. Congress of Speleol., Chaux-de-Fond, Switzerland 2: 99102.

Roberts N, Smart P.L., Baker A., 1998 - Annual trace element variations in a holocene speleothem. Earth and Planetary Science Letters 154: 237-246.

Roberts M.S., Smart P.L., Hawkesworth C.J., Perkins W.T., Pearce N.J.G., 1999 - Trace element variations in coeval Holocene speleothems from GB cave, Southwest England. The Holocene 9 (6): 707713.

Verheyden S., Keppens E., Fairchild I.J., Mc Dermott F., Weis D., 2000 - Mg, Sr and Sr isotope geochemistry of a Belgian Holocene speleothem: implications for paleoclimate reconstructions. Chemical Geology 169: 131144.

White W.B., 1997 - Color of speleothems. In : Hill C.A. and Forti P. (Eds.): Cave minerals of the world. National Speleological Society: 239244. 